\title{
MOSÉN SOL Y LA REPARACIÓN
}

ROMÁN SÁNCHEZ CHAMOSO 1

DOI: https://doi.org/10.52039/seminarios.v55i191.504

Todos los valores son encarnados. El autor inicia su espléndido trabajo ubicando en la historia social y de la espiritualidad del s. XIX la experiencia de la reparación eucarística. Sin embargo, el ambiente histórico no define. Por ello el autor indaga en la relación evidente entre Eucaristía y reparación. La Eucaristía que compromete, que vincula a la persona con Jesucristo que se ofrece como expiación. Pero, aún más la reparación a Jesús sacramentado tiene una dimensión verdaderamente personal que sólo puede captarse desde esa peculiar cristología que el Beato Manuel Domingo y Sol vivió y transmitió: la reparación es cosa que se entiende desde el ser amigos. Como dice el autor, Jesucristo reivendica el corazón en sus relaciones con sus discípulos.

1 Sacerdote Operario Diocesano. Doctor en teología por la UPSA. Actualmente profesor en el seminario santa Rosa de Lima de Caracas y en el seminario Jesús Buen Pastor de Ciudad Bolívar, Venezuela. 
INTRODUCCIÓN, (11); 1. LA REPARACIÓN EN MOSÉN SOL Y SU TIEMPO, (12); 1.1. Contexto socio-religioso del siglo $X I X,(12) ; 1.2$. Presupuestos básicos desde los que se fragua la reparación en el Beato Manuel Domingo y Sol, (13); EUCARISTÍA, (14); CORAZÓN DE JESÚS, (15); REIVINDICANDO EL CORAZÓN (18); 1.3. Relación Eucaristía-Corazón de Jesús-reparación en Mosén Sol, (20); 1.4. Concepto de reparación, (21); 1.5. En sintonía con la Iglesia de su tiempo, (24); 1.6. Proyección de la idea de reparación de Mosén Sol, (25); 1.7. Espiritualidad eucarística (28); 1.8. Prácticas eucarístico-reparadoras (29); 1.9. Templos de reparación (30); 2. LíMITES Y VALORES DE LA REPARACIÓN TRADICIONAL, (32); 2.1. Límites, (32); Cristológico, (32); Antropológico, (32); Espiritual, (33); 2.2. Valores, (33); La intimidad con Cristo, valor permanente, (33); El amor debe ser correspondido re-damatio, (34); Ante la soledad y abandono de Jesús, (35); Frente al peligro del activismo y la exterioridad con olvido de la profundidad, (36); También los sentimientos, (36); La reparación ante el nuevo milenio (37); 3. EL NÚCLEO DE LA REPARACIÓN DE MOSÉN SOL; ABIERTO A LA MODALIDAD ACTUAL DE REPARACIÓN, (38); 3.1. EI núcleo de la reparación en el Beato Manuel Domingo y Sol, (38); 3.2. Relectura de Mosén Sol desde la perspectiva de la reparación actual, (40).

\section{Siglas}

AG: Asamblea General. Las Asambleas de la Hermandad se citarán con la sigla AG seguida del orden de las Asambleas en números romanos y de la Conclusión de la Asamblea en números arábigos (V. gr. AG V, 8)

Const.: Constituciones redactadas por Mosén Sol y los primeros operarios

CSCJ: Culto al Sagrado Corazón de Jesús en el nuevo milenio, Monte Carmelo,

Burgos 2000, por F. López Rivera-C. Soltero-Mª. Celayeta

D: Dehoniana. Revista de los Sacerdotes del Sagrado Corazón de Jesús

DM: Dives in misericordia. Encíclica de Juan Pablo II (1980)

DS: H. Denzinger-A. Schönmetzer, Enchiridion symbolorum

Escritos: Manuscritos de Mosén Sol. Archivo de la Hermandad en Roma. Consta de 3 apartados: I. Predicación, II. Cartas, III. Varia

HA: Haurietis aquas. Encíclica de Pío XII (1956)

IdH: La Idea de la Hermandad de Sacerdotes Operarios Diocesanos. Compilación de textos originales del Fundador, Algueró y Baiges, Tortosa 1957, por P. Ruíz de los Paños

MR: Miserentissimus Redemptor. Encíclica de Pío XI (1928)

PyE: Pensamiento y espíritu del Siervo de Dios Manuel Domingo y Sol. Textos originales, Algueró y Baiges, Tortosa 1956.

RBMDS: La reparación en el Beato Manuel Domingo y Sol. Cuadernos Mosén Sol $n^{\circ} 8$. Centro de Estudios Mosén Sol, Tortosa 1995, por A. Hernández Casero RMSR: Riparazione: mistero di spiazione e di riconciliazione, EDB, Bologna 1978, por G. Manzoni

SOD: Sacerdotes Operarios Diocesanos. Aproximación a su historia, Sígueme, Salamanca 1996, por L. Rubio-J. de Andrés-F.Martín

TN: Tierra Nueva. Revista chilena que recoge numerosos trabajos posteriores al Vaticano II sobre el Corazón de Jesús, publicados entre 1975 y 1995. Puede ser especialmente útil para el lector latinoamericano V. K. Salomón, Un aporte a la reflexión actualizada del Corazón de Jesús en la Hermandad-Tesina mecanografiada-, Caracas 1996 (Ofrece la referencia de 96 trabajos) 


\section{INTRODUCCIÓN}

El motivo inmediato del presente trabajo es la celebración del I Centenario de la muerte del Beato Manuel Domingo y Sol. Estudiaremos su concepto de reparación, ubicándolo en el contexto teológico-espiritual en que vivió.

La idea de reparación es central en el pensamiento, vida y obra de Mosén Sol. Su planteamiento debe situarse, ante todo, en el campo de la espiritualidad y en el de la piedad popular, que se proyectará en la praxis pastoral (prácticas de piedad) de Mosén Sol y su tiempo. La teología en la que se sustenta es la entonces dominante y comúnmente aceptada en la Iglesia del siglo XIX.

Esta concepción de la reparación llega, en términos generales, hasta el umbral del Vaticano II. La denominaremos reparación tradicional para distinguirla de la reparación actual, que tiene como soporte la teología conciliar. Aclaremos que estos términos: tradicional y actual, deben entenderse inicialmente en sentido sociológico-religioso, sin que entrañen en principio por nuestra parte descalificación o canonización alguna. Depende de si en la mirada predomina la referencia al pasado o al futuro, con el Vaticano II como línea divisoria convencional.

¿Es actual hablar hoy de reparación? Presentar en nuestros días un estudio sobre la reparación no es tarea fácil por sus connotaciones pietistas, más propias quizás de una espiritualidad de otras épocas, en las que predominaba lo afectivo, se exaltaba la fuerza del sentimiento y adquiría su máxima expansión en manifestaciones entusiastas de piedad y de múltiples devociones (RBMDS, 7) Esta dificultad es real, pero su impopularidad no debe excusarnos de buscar, más allá de las formas y formalismos epocales, el contenido teológico-espiritual-pastoral que la reparación encierra.

Tomaremos nota de dos enfoques o modos de entender la reparación. Veremos que no cabe duda que en Mosén Sol y su época domina la que hemos llamado tradicional, lo que no le priva de un valor actual como mostraremos en su momento. Recordemos lo ya señalado: se movían más en el área de la espiritualidad que en el de la teología. Por nuestra parte, en este trabajo conjugaremos la teología, la espiritualidad y la historia.

El término reparación no tiene origen bíblico, sino litúrgico-patrísticodevocional (Cf. RMSR, 5-6), pero sí tiene el contenido o concepto bíblico. Un sondeo sobre publicaciones bíblicas nos aporta conceptos teológicos afines al de reparación, tales como redención, satisfacción, expiación, oblación, reconciliación, intercesión...2. Estos términos son afines al de reparación porque ponen de relieve el aspecto real, objetivo de un bien arruinado, que debe ser restablecido y vuelto a su integridad. 


\section{LA REPARACIÓN EN MOSÉN SOL Y SU TIEMPO}

\subsection{Contexto socio-religioso del siglo XIX}

Para entender correctamente la idea de reparación que tuvo el Beato Manuel Domingo y Sol, debemos tomar conciencia del contexto en el vive en el contexto de la España en la segundo mitad del siglo XIX³, época de insultos, atropellos y violencias que llegan incluso a la blasfemia oficial y pública. Lamentable exponente de ello es la tristemente famosa Sesión de las blasfemias en las Cortes (26 de abril de 1869), en la que un diputado ateo y médico llegó a declarar la guerra a Dios, a los reyes y a la tuberculosis. En este contexto, es comprensible la reacción de Mosén Sol y de tantos otros contemporáneos para contrarrestar aquella avalancha de agravios con la predicación y las prácticas piadosas de desagravio. Se explica así el vocabulario al uso al tratar de la reparación: desagravio ante las ofensas, injurias, ultrajes inferidos a Dios, y, para contrarrestarlo, la compasión, expiación, consuelo, ofrecimiento como víctima... al Corazón angustiado de Jesús. Y esto explica, además, como veremos más adelante, la puesta en pié de la red de reparadores que emprende Mosén Sol, implicando a todos los estamentos eclesiales en la empresa reparadora.

Se pone en macha una cruzada reparadora. Don Manuel Domingo y Sol muestran una total afinidad con los apóstoles insignes de la devoción al

2 Cf. J. Solano, Reparation in devotion to the Sacred Heart of Jesus en The Apostleship of Prayer 1-3 (enero 1973) 111; G. Manzoni, RMSR; A. Tessarolo, Expiación en E. Ancilli (dir), Diccionario de Espiritualidad, II, Herder, Barcelona 1993, 91-92; B. Studer, Expiazione en A. Di Berardino (dir), Dizionario Patristico e di antichità cristiana, I, Marietti, Casale Monferrato 1983, col. 1232-1235; J. Hartmann, Le sens plènier de la réparation, Lovaine 1955; A Pellin, Vida de reparación, Madrid 1966; G. Denis, Spiritualità riparatrice, Pescara 1955; G. Mengali, La intercesión bíblica (o bien, la solidaridad reparadora) en D 102 (2000-2) 556-66.

La revista chilena TIERRA NUEVA (Sigla: TN) ofrece una serie de trabajos en los que aparece la relación entre Sagrada Escritura y reparación: M. A. Barriola, El Corazón de Cristo, camino viviente de la Nueva Alianza: 32 (1980) 42-63; Id., El Costado traspasado como tema estructurante del Apocalipsis , I y II: 43 (1982)68-88 y 44 (1983)62-75; Id., El Corazón herido de Jesucristo, compendio de la Nueva y Eterna alianza. Meditación bíblica: 69 (1989) 72-92; I. de la Potterie, Fundamento bíblico de la teología del Corazón de Jesús. La soberanía de Jesús; su obediencia al Padre; su conciencia filial: 40 (1982) 55-76; Id., Contemplar el Corazón traspasado. Homilías: 89 (1994) 73-76; S. Lyonet, ...salió sangre y agua: Jn 19, 34: 71 (1989) 62-69; Ph. Jobert, Mt 1, 29: Sean mis discípulos, porque soy manso y humilde de corazón: 76 (1991) 67-78; M. Soler, Jesús el Traspasado: 87 (1993) 72-82

3 Cf. SOD, 20ss. 
Corazón de Jesús. Ciñéndonos a la Compañía de Jesús, pionera de esta devoción, señalaremos al P. Bernardo F. de Hoyos (1711-1735), quien se expresa en estos términos: Da dolor por la cruz casi continua de las ofensas que se han cometido, cometen y cometerán contra el Señor, y en especial de las ingratitudes que en la Eucaristía ha experimentado su amante Corazón ${ }^{4}$. Similares sentimientos encontramos en el P. Francisco de Paula Tarín (1847-1910), riguroso contemporáneo de Mosén Sol5.

Las raíces del talante reparador dominante habría que buscarlas en el siglo $\mathrm{XVII}$. Traspasando las fronteras patrias, echemos una mirada al contexto de la Francia del siglo XIX7. Nos fijamos en una figura representativa, el P. León Dehon, por su afinidad con Mosén Sol en el tema de la reparación, al punto de que podemos hablar de almas gemelas. Las afinidades entre ambos salta a la vita. EI P. Dehon y Mosén Sol son rigurosamente contemporáneos y respiran el mismo aire eclesial y pastoral, pueden ser vistos como caso-tipo de la reparación en su época 8 .

Fruto y exponente del contexto descrito es la afloración de números Institutos religiosos, masculinos y femeninos, surgidos en el siglo XIX, puestos bajo el Corazón de Jesús como especificador de los mismos, con el consiguiente enfoque y práctica piadosa reparadora.

\subsection{Presupuestos básicos desde los que se fragua la reparación en el Beato Manuel Domingo y Sol}

Debemos tener en cuenta el carisma concreto de Mosén Sol. A cada

4 J. E. Uriarte, Vida del P. Bernardo F. de Hoyos, Administración El Mensajero, Bilbao 1913, 361

5 J. Ma . Granero, El misterio de un apóstol, BAC popular, Madrid 1983. Añádase a los anteriores, con una orientación más práctica y devocional, al P. Francisco Javier Quintana (1892-1970), Doctrina y práctica de la devoción al Sagrado Corazón de Jesús, Imprenta Rebollar, México 1955: El fondo de mi vida espiritual es el amor reparador, consolador, suplicador y glorificador al Sagrado Corazón, y propone el apostolado de sustitución para dar gloria a Dios, la gloria que otros no le dan, y usa la fórmula Corazón eucarístico de Jesús, idéntica a la de de Mosén Sol: Corazón de Jesús sacramentado.

6 Cf. A. Edwards, La devoción al Corazón de Jesús y la cultura del siglo XVII en TN (45 (1983) 62-77, que se propagará en los siglos siguientes.

7 Cf. G. Manzoni, La spiritualitá riparatrice in Padre Dehon, Centro Generale Studi, Roma 1996, 73-92

8 Cf. Ibid., especialmente pp. 38-40.95.116.129-129 para constatar dichas afinidades. Más en concreto por lo que se refiere al P. Dehon, cf. P. J. McGuire, El mundo del corazón en el corazón del mundo en TN 102 (2000-2) 33-51. 
carisma se le ha dado destacar una palabra de la Palabra. La Palabra de Dios se lee y se entiende a través del carisma dado al fundador. Veamos los presupuestos básicos del carisma de Mosén Sol. Procuraremos dejarle a él la palabra, añadiendo por nuestra parte breve glosa.

\section{EUCARISTÍA}

Circunscribiéndonos ahora al tema de la reparación, ésta no puede entenderse en Mosén Sol sin el trasfondo de la eucaristía. Mosén Sol transpiraba eucaristía por todos sus poros, y proyecta la eucaristía en todas sus obras: Mihi vivere, Christus in sacramento. Nuestra vida interior sea Jesús sacramentado y olvidado. Con esto seremos perfectos" (Escritos, V, 1) Mosén Sol nos dice que profesaba un instintivo amor a Jesús Sacramentado (IdH, 257)

El mismo origen de la Hermandad por él fundada se encuentra en la eucaristía: La Hermandad me la inspiró Jesús Sacramentado el 29 de enero de 1883, durante la acción de gracias después de la misa (PyE, 8) La idea de la Hermandad germinó a los pies de Jesús Sacramentado (PyE, 111)

Y del origen, Mosén Sol pasa a los cometidos de la Hermandad: El origen de nuestro deseo de fomentar las vocaciones sacerdotales ha sido nuestro amor a Jesús Sacramentado (PyE, 279). En la Hermandad se actuará unidos al Jesús Sacramentado de nuestros amores (PyE, 299) Los testimonios podían multiplicarse ${ }^{9}$.

La eucaristía es el lenitivo de Mosén Sol para afrontar las adversidades y para recobrar la paz. Respondiendo a un operario que le comunica sus problemas, escribe: Con cinco minutos de pensamiento en la eternidad y una visita a Jesús sacramentado desaparece toda aspereza del Corazón (PyE, 79; cf. 216).

Recomienda a los operarios que en los viajes no dejen de saludar a Jesús en las parroquias, al pasar por las estaciones y cuando penetren y pasen por los pueblos (PyE, 251) La eucaristía debe englobar la jornada del operario. El saludo mañanero ha de ser: Jesús Sacramentado. Sea por siempre alabado", y la despedida por la noche: Sea por siempre alabado el Corazón de Jesús sacramentado, y al despertar cada día se dirá: Viva el

9 Tengo confianza de que Jesús nos llama para obras muy visibles respecto a la propagación del culto a su Amor Sacramentado (PyE, 279). Tanto es el deseo de que Jesús nos escoja a nosotros para ser instrumentos de su amor eucarístico en España (IdH, 277). La propaganda eucarística, objeto tan especial de la Hermandad, Ilena todos los anhelos de mi espíritu y de fruición 'cor meum et carnem meam' (PyE, 279). 
Corazón de Jesús sacramentado. Gloria al Corazón de Jesús sacramentado (PyE, 100) La primera fórmula de la consagración de lo operarios redactada por don Manuel comienza así: Dulcísimo Corazón de Jesús Sacramentado, amable Salvador de mi alma (año 1885).

A los alumnos-colegiales de Roma les confiesa: ¡Nos habéis costado más oraciones ante Jesús Sacramentado de lo que vosotros podéis creer (PyE, 198).

Mosén Sol encuentra en Jesús sacramentado el apoyo, el aliento, el consuelo y anhelo de su corazón, y en él se inspira para el sacrificio y la vocación de víctima. El acto de oblación nace de la fuente de la eucaristía, ahí aprende el camino del servicio, de la entrega y de la inmolación victimal. Sin Jesús sacramentado, ¿qué sabríamos de amor, de abnegación, de sacrificio?

El amor a Jesús sacramentado y su fomento lo ve Mosén Sol como el motor e impulsor del trabajo de los operarios en los seminarios, en la pastoral femenina, en la juventud y en las diversas obras de apostolado (Cf. IdH, 258-262). Lo dice bien explícitamente: Jesús sacramentado será indudablemente el móvil de todas nuestras operaciones (IdH, 263), de él depende totalmente la vida y el quehacer de la Hermandad: El reinado de Jesús sacramentado vivificará nuestra Obra (IdH, 268).

\section{CORAZÓN DE JESÚS10}

La devoción al Corazón de Jesús dominaba en tiempos de Mosén Sol como él mismo confiesa: Cada época tiene sus necesidades. Somos cristianos de este siglo, el siglo del Corazón de Jesús. Debemos cumplir, pues, las obligaciones de este siglo (PyE, 97; cf. 246) Es una idea ampliamente compartida. La devoción al Corazón de Jesús se convierte en la expresión más popular de la piedad del siglo XIX11. Con esta devoción se frecuenta la escuela del amor para llevar este amor a un mundo frío y sin corazón. Esta devoción procede de la base del pueblo de Dios, no del magisterio ni de la teología, es un movimiento popular genuino.

10 Corazón de Jesús y reparación: cf. B. de Margerie, El Corazón de Jesús, principio y término de nuestra reconciliación penitente en TN 48 (1984) 56-61; M. González Martín, La reconciliación y la penitencia a la luz del Sagrado Corazón de Jesús en TN 51 (1984) 77-84; J. Tomko, El Corazón de Jesús, símbolo de misericordia en el sacramento de la penitencia en TN 54 (1985) 52-62; C. Pozo, La teología del Corazón de Jesús en la crisis actual del pensamiento teológico en TN 66 (1988) 70-75; Id., El misterio del Corazón de Cristo en la teología actual en TN 70 (1989) 81-94; E. Glotin, La verdadera reparación solicitada por el Corazón de Jesús en TN 79 (1991) 72-79.

11 P. J. McGuire, a.c., 43 
Mosén Sol puso al Corazón de Jesús en la cabecera de la Hermandad en la primera redacción de bases y reglas: El titular de la Hermandad es el Corazón de Jesús (Const 6; cf. IdH, 476)), es el emblema especial del escudo y sello de la Hermandad (PyE, 94).

Vuelve constantemente sobre esta idea, inculcándola en los operarios, hasta el punto de que debe ser el sentimiento peculiar, constante, tierno, interior de nuestros corazones (Escritos, I, 5, 31) y el móvil de todas nuestras operaciones (PyE, 94), el que ha de regular nuestros actos, y a quien debemos acudir en las pruebas y necesidades..., es el centro de todas nuestras devociones (IdH, 476; cf. PyE, 42, 90, 251, 279). Entre las condiciones de los que aspiran a incorporarse a la Obra incluye un celo animoso, vivificado por el más delicado y constante sentimiento de reparación al Corazón de Jesús (Const 3), y desearía extenderla a todos los sacerdotes, hasta inundar las parroquias de apóstoles del Corazón de Jesús (PyE, 242). Esta devoción rebasa el sentimentalismo y apunta a los más sólido: La mejor devoción al Corazón de Jesús es imitar sus sentimientos y sus afectos (Escritos, I, 1, 113), en la más estricta línea paulina.

La Hermandad es para don Manuel obra del Corazón de Jesús, como expusimos anteriormente y que él repite con frecuencia: Nuestra Obra ha brotado del Corazón de Jesús Sacramentado, silencioso, olvidado, desconocido, ultrajado (PyE, 94; cf. 77; IdH, 111). En esta peculiar manera de ver al Corazón de Jesús -silencioso, olvidado, desconocido, ultrajadose esboza en filigrana el tipo de reparación que debe tributársele.

De esta devoción vivamente encarnada se deriva el intenso y multiforme apostolado para incrementarla (Cf. PyE, 37, 101), que establece como tercer objeto de la Hermandad y así sueña con extenderla a toda España (Cf. PyE, 281).

La confianza y familiaridad de don Manuel con el Corazón de Jesús no tiene límites. Ahí encontraba su reposo y su estímulo para la inmolación, como lo fue para su alma gemela, el P. Dehon ${ }^{12}$. Con esta llaneza se expresa Mosén Sol: Todo lo ha de hacer el Corazón de Jesús, y El me lo hace todo, y más de lo que pido, en lo que es de su voluntad y agrado; y no sé por qué miseria he de ser tan miserable en no acudir más a El, pues el día en que más mal me porto, más me humilla con sus bendiciones (PyE, 300) Este otro testimonio nos muestra la singular familiaridad con el Corazón de Jesús: Dios mío, por manos de María Inmaculada os ofrezco el

12 Nuestro lugar de reposo en la oración es el Corazón de Jesús, sus misterios de amor y de inmolación (P. Dehón, Directorio espiritual, V, 1) 
Corazón de Jesús Sacramentado y os lo ofrezco sacrificado. Es mío y me pertenece. Pudiera no ofrecerlo, como no piensan en ofrecerlo otras almas; yo, por amor a Vos, lo recibo y os lo ofrezco (IdH, 270).

Para el Beato Manuel Domingo y Sol, la devoción al Corazón de Jesús es motivo no meramente sentimental, sino de justicia (Cf. Escritos, I, 1, 103)13.

Si nos asomamos a su apostolado sobre el Corazón de Jesús, la vida de Mosén está jalonada de obras concretas de cara al pueblo, con un extenso itinerario en el espacio y en el tiempo ${ }^{14}$

Hay que recuperar el corazón como imagen y expresión del amor de Dios. Don Manuel lo expresa con toda claridad y precisión teológica: El Corazón de Jesús no solo es señal, no solo es un símbolo de su amor para con nosotros, sino que también ha sido el conducto, el órgano principal de este mismo amor. Por eso, no nos extrañemos que él mismo haya querido ser honrado principalmente en su corazón (Escritos, I, 1, 103).

Al hablar del Corazón de Jesús nos debemos alejar por igual del sentimentalismo y del puro biologismo15. Al paso de ello sale la devoción al Corazón de Jesús, recabando para el corazón la centralidad en la vida espiritual. Santa Margarita María de Alacoque y la devoción a partir de ahí entiende el Corazón de Jesús como trono de llamas de amor, como la imagen de la persona de Jesús en su más profunda identidad: es la imagen simbólica del corazón. Hoy los estudios bíblicos han abundado en la simbología del corazón ${ }^{16}$. El lenguaje bíblico expresa por corazón más que solo los sentimientos y la vida afectiva. Indica lo que hay de más íntimo en el hombre. Abarca sus razonamientos, sus proyectos, sus recuerdos, su conciencia. Corazón es la interioridad de la persona: El centro de la persona es lo que la Biblia llama el corazón ${ }^{17}$. Al testimonio de la Biblia se

13 Idea que repetirá años después Pío XI en MR.

14 En 1871 se consagra en San Juan (Tortosa) como apóstol de la devoción al Corazón de Jesús. En 1873 establece el Apostolado de la Oración en Ulldecona, Gandesa, Alcanar, Santa Bárbara y otros pueblos; en 1882, en Villafranca y otros pueblos; en 1883, en Tivisa y Benicarló, en 1888, en Benasal; en 1889, en Vinaroz, Onda y Lucena del Cid; en 1891, en dos parroquias de Valls de Uxó; en 1893, en Artana... La culminación de este itinerario la ve Mosén Sol en 1903 con el Templo de Reparación de Tortosa.

15 El materialismo del siglo XIX redujo el corazón a una simple víscera del cuerpo humano, a una bomba mecánica. Para este materialismo, lo que cuenta y vale es la mano, la cabeza y el cerebro, no el corazón

16 Cf. C. Pozo, Simbología del corazón en la Biblia y en la tradición cristiana en TN 90 (1994) 71-80; G. Arias, Un corazón para siempre, Buena Prensa, México 1996; P. J. McGuire, a.c. en D 102 (2000-2) 33-51

17 Juan Pablo II, Catequesis general (8 de junio de 1994); cf. Id., DM, 13 
suma el de la antropología: Mientras el hombre tenga corazón, tendrá que hablar de corazón. Es decir, siempre... Pero hay que saber qué significa corazón y qué infinito cuando se quiere hablar del Corazón de Cristo ${ }^{18}$.

Al hablar del Corazón de Jesús nos referimos al amor humano de una persona divina, a un Corazón traspasado y abierto, que revela el amor misericordioso del Padre y que nos da el Espíritu Santo. Toda la Trinidad queda implicada en la humanidad del Hijo. Cristo -como dice el Vaticano II, el Verbo encarnado, nos amó con corazón de hombre (GS 22b). Así lo ha entendido la gran tradición eclesial. La devoción al Sagrado Corazón de Jesús fue la respuesta al rigorismo jansenista, que había acabado por desconocer la infinita misericordia de Dios ${ }^{19}$. El Corazón de Jesús -nos dirá Pablo VI- es la hoguera ardiente de caridad, símbolo e imagen expresiva del amor eterno con el que Dios tanto amó al mundo que le dio a su Hijo unigénito: Jn 3, $16^{20}$.

\section{REIVINDICANDO EL CORAZÓN}

La antropología y la teología reivindican hoy el rico significado del corazón. Corazón es una palabra fundamental en toda la humanidad. Por otra parte, pocas palabras como ésta aparecen con más frecuencia en la Biblia. Por tanto, desde el punto de vista antropológico como desde el bíblico-teológico está preñada de un rico y fundamental contenido. La devoción al Corazón de Jesús apunta al contenido central de la verdadera religión, la religión del amor. Esta religión es denominada el 'culto del amor' y, por ello, la 'gran religión'. En ella, Dios nos atrae hacia su corazón y nos lleva al amor al prójimo con su mismo amor. Este es el rico contenido que expresa de modo palpable la devoción al Corazón de Jesús21.

Juan Pablo II, en la encíclica Redemptor hominis, usa indistintamente las expresiones Corazón de Jesús, Corazón de Cristo y otras similares. Lo mismo encontramos en el rico magisterio de la Iglesia, que establece una íntima relación entre la devoción al Corazón de Jesús y la reparación ${ }^{22}$.

18 K. Rahner, Escritos de Teología, III, Taurus, Madrid 1961, 357-367

19 F. Cerro Chaves, Encíclicas y documentos de los papas sobre el Corazón de Jesús, Monte Carmelo, Burgos 2000, 317-318

20 Carta apostólica Investigabiles divitias, 5

21 B. Häring, El Sagrado Corazón y la salvación del mundo, Ed. Paulinas, Bogotá 1984. 
El Corazón de Jesús es el símbolo del amor de Cristo, icono de la Palabra de Dios hecha carne ${ }^{23}$. Pío XII, en HA, recurre a varias imágenes: es la imagen del amor divino y humano del Redentor (Cf. nn. 34.39.50.58), fuente de caridad divina (n. 42), imagen viva de la infinita caridad de Dios (n. 39), y de Jesucristo (nn. 12.28), y de la misericordia de Dios (n. 55), que

22 Principales documentos:

León XIII, Enc. Annum sacrum (1899) Pío XI, Enc. Quas primas (1925). Originariamente titulada De communi expiatione Cordi lesu debita; Id., Enc. Miserentissimus Redemptor (1928), en la que el papa centra su atención en el espíritu de expiación y reparación, que tiene la primacía y la parte más principal en el culto al Santísimo Corazón de Jesús (n. 9), y habla del grato deber de consolar a Cristo (n. 10); Id., Enc. Caritate Christi compulsi (1932), donde vincula Corazón de Jesús y eucaristía

Pío XII, Enc. Summi pontificatus (1939), el Corazón de Cristo Rey es el único que puede sosegar la tempestad y desterrar los espíritus de discordia que la provocaron (n. 77) (Se refiere a la II Guerra mundial); Id., Enc. Haurietis aquas (1956), donde sienta el fundamento teológico del culto al Corazón de Jesús, y lo vincula con la eucaristía (Cf. nn. 20.35).

Hasta aquí, el magisterio se mueve en el concepto tradicional o negativo de reparación. A partir de ahora, con Pablo VI y Juan Pablo II, se introduce en el magisterio el concepto actual o positivo de reparación:

Pablo VI, Carta apostólica Investigabiles divitias (1965), donde se resalta la relación entre Corazón de Jesús y eucaristía: la eucaristía es el mayor regalo del Corazón de Cristo, en consonancia con el Vaticano II; Id., Carta Diserti interpretes (1965), dirigida a los Superiores mayores de los Institutos dedicados al Corazón de Jesús. Juan Pablo II, Enc. Redemptor hominis (1979); Id., Enc. Dives in misericordia (1980), sobre el amor fontal del Dios trinitario revelado en Cristo; Id., Carta al Prepósito general de la Compañía de Jesús (1986) y Carta al Prepósito general de la Compañía de Jesús en Paray-le-Monial (1999), revalorizando la devoción al Corazón de Jesús. (Estos documentos pueden encontrarse en castellano en F. Cerro Chaves, Encíclicas y documentos de los papas sobre el Corazón de Jesús, Monte Carmelo, Burgos 2000). Para literatura teológica sobre este magisterio, cf. F. López-C. Soltero- Ma ${ }^{\text {. Celayeta, }}$ CSCJ. En la ya citada revista TN hay varios trabajos: J. Ratzinger, El misterio pascual y el culto al Corazón de Jesús: 40 (1982) 77-86; F. Hausmann, Haurietis aquas. Acotaciones acerca de la comprensión dogmática de la devoción al Corazón de Jesús en la encíclica de Pío XII: 42 (1982) 78-92; R. Sánchez-Arjona, La encíclica Haurietis aquas y la futura pastoral popular de la devoción al Corazón de Jesús en Latinoamérica: 51 (1984) 85-93; E. Glotin, Juan Pablo Il en Paray-le-Monial, o ipor qué el 'corazón'?: 62 (1987) 79-93; A. Bandera, La voluntad salvífica universal en la encíclica Dives in misericordia y el culto al Corazón de Jesús: 67 (1988) 87-94; L.

Mendizábal, El Corazón de Jesús en la vida y en la enseñanza de Juan Pablo Il: 68 (1989) 79-96; J. A. Goenaga, El Corazón del Señor en el Catecismo de la Iglesia Católica: 86 (1993) 72-80.

23 Cf, Pablo VI, Carta apost. Investigabiles divitias, 5. 
es rico en misericordia (n. 42) Traspasado por nuestros pecados y por nuestra salvación (cf. Jn 19, 34), el Corazón de Jesús es considerado como el principal indicador y símbolo del amor con que el divino Redentor ama continuamente al eterno Padre y a todos los hombres ${ }^{24}$.

Terminamos este apartado con un sugestivo testimonio sobre la devoción al Corazón de Jesús y el camino de los pobres. Es del P. Arrupe dirigiéndose a los jesuitas: Ustedes repiten muchas veces que los pobres les han enseñado más que los libros; entonces, aprendan de ellos esta lección evidente: amen a Jesucristo, entrando por la puerta del amor sencillo de su Corazón 25 .

\subsection{Relación Eucaristía-Corazón de Jesús-reparación en Mosén Sol}

El Beato Manuel Domingo y Sol recurre a una expresión feliz que repetirá una y otra vez: Corazón de Jesús Sacramentado. Ahí pone el foco de la reparación 26 .

Al sentar la naturaleza de la Hermandad, señala tres aspectos, al segundo de los cuales llama espíritu de la Hermandad, y dice: Reparación por las ofensas a su amor en la Eucaristía (PyE, 37). A Mosén Sol le resulta fácil, diríamos que espontáneo, unir Eucaristía, Corazón de Jesús y reparación: Intensa devoción al Corazón de Jesús y delicado espíritu de reparación a El, especialmente en el Santísimo Sacramento (PyE, 37; cf. Const 4, 28, 34).

Corazón de Jesús y Eucaristía son inseparables en Mosén Sol, y entre ellas actúa como puente la reparación. La vida espiritual del Beato Mosén Sol aparece continuamente movida por dos polos de fuerza: la Eucaristía y el Sagrado Corazón, y entre ellos hay un puente que los convierte en forma de vida: la reparación. Es el amor hecho compromiso27. De ello se hace eco el Decreto por el que se confiere a la Hermandad la naturaleza de instituto secular (19 de marzo de 1952): Con el alma puesta en la reparación y expiación hacia el Corazón de Jesús, sobre todo en el santísimo sacramento del altar...28.

24 Pío XII, DS 3924

25 Citado por L. López-C. Soltero-Ma . Celayeta, CSCJ, 18

26 La expresión aparece en la fórmula primera de la consagración a la Hermandad (1885) y queda sembrada a lo largo de sus escritos: cf. PyE, 93, 94, 100, 251..., y Escritos, III, $1^{\circ}, 60,61,62 \ldots$

27 RBMDS, 9

28 SOD, 566 
Es frecuente en la vida de los santos vincular la reparación de los pecados a la Eucaristía y al Corazón de Jesús ${ }^{29}$. También el magisterio lo pone de manifiesto ${ }^{30}$, hasta el punto que en Juan Pablo II resulta muy familiar ${ }^{31}$.

\subsection{Concepto de reparación}

Es llegado el momento de preguntarnos: ¿Qué entendía Mosén Sol por reparación, en qué consistía para él?

La centralidad de la reparación en la espiritualidad, vida y obra de don Manuel está fuera de toda duda. Pero no escribió un tratado sobre el terma, sino que lo sintió y vivió profundamente. Nunca se propuso hacer un sistema orgánico de sus ideas, sino que trató simplemente de comunicarlas.

No redactó un tratado, sino que dio rienda suelta a sus vivencias espirituales, creando así un estilo de vida. Mosén Sol es un magnífico exponente de la idea de reparación en su tiempo y, en sintonía con éste, domina en él claramente la llamada reparación negativa, afectiva y aflictiva32.

Comencemos por el vocabulario como primera aproximación a su idea de reparación, destacando algunos términos característicos. Sacrificio sería el concepto dominante e informador de su idea de reparación; estrechamente ligado a él por ser el fundamento del sacrificio, aparece el término amor a quien tanto nos amó, y el término expiación a quien tanto ofende el pecado, de donde surge el sentimiento por las ofensas y ultrajes inferidas al Señor y la compasión o conmiseración con el Señor ofendido. Todo ello conduce a

29 Cf. RBMDS, 12-13. La relación Corazón de Jesús-Eucaristía es muy fuerte en el

P. Dehon: cf. G. Manzoni, La spiritualità riparatrice in Padre Dehon..., 189-191

30 Cf. Pablo VI, Carta apostólica Investigabiles divitias, 6.8

31 Del Corazón amorosísimo de Jesús proceden todos los sacramentos $y$, especialmente, el mayor de todos, el sacramento del amor, por el cual Jesús ha querido ser el compañero de nuestra vida, el alimento de nuestra alma, sacrificio de un amor infinito (San Alfonso María de Ligorio, citado por Juan Pablo II en Mensaje del Papa al arzobispo de Lyon, n. 3 (4 de junio de 1999): puede verse el texto en F. Cerro Chaves, Encíclicas y documentos..., 329). La contemplación del Corazón de Jesús en la Eucaristía... Toda la devoción al Corazón de Jesús en sus diversas manifestaciones es profundamente eucarística (Juan Pablo II, Mensaje del Papa en la fiesta del Sagrado Corazón. Varsovia, 2g (11 de junio de 1999): textos en F. Cerro Chaves, O.c., 328.330).

32 Cf. RBMDS, 28-31 
ofrecerse como víctima de reparación para compensar el desafecto de los hombres y a fomentar el celo eucarístico-reparador de los amigos de Jesús comprometidos con él y su causa, sentida como propia ${ }^{33}$.

Una primera postura ante este vocabulario puede ser considerarlo superficial, sentimental y poco comprometido. Pero hemos de llegar al amor que se encierra en ese com-padecer, que apunta a tener los mismos sentimientos de Cristo y a participar de sus actitudes: com-padecer implica una previa identificación, lo que desemboca en asumir el sufrimiento que conlleva la vida con talante positivo, como expresión de solidaridad con los que sufren. La muerte asumida con esta actitud es verdadera reparación.

Vamos a ceder la palabra a Mosén Sol para ver el perfil que en él tiene la reparación. Éstas serían sus principales ideas-fuerza:

- Ve a Jesús angustiado: Corazón angustiado y desgarrado de Jesús (PyE, 207, 299), de donde brota el sentimiento interno de amor y compasión a Jesús sacramentado (PyE, 279).

- Ante las ofensas, injurias y ultrajes: Reparación por las ofensas a su amor en la Eucaristía" (PyE, 35) y las injurias al Corazón de Jesús (PyE, 86). La vivencia personal de Mosén Sol la refleja cuando nos dice que la Hermandad ha brotado del Corazón de Jesús Sacramentado silencioso, olvidado, desconocido, ultrajado (PyE, 94) y hay que reparar las injurias a su Corazón (Const 110-111; cf. Escritos, I, $\left.5^{\circ}, 24,27,29\right)$. Más aún, quiere religiosas reparadoras del amor ultrajado del Corazón de Jesús (PyE, 268). El celo que Mosén Sol expone en el Reglamento lo explicita como el sentimiento por la pérdida de los intereses de Jesús, las injurias a su Corazón (IdH, 446).

- Actitud de expiación y sacrificio34. Don Manuel cree que el ejercicio interior de expiación y sacrificio y de compasión a Jesús es el más eficaz para repararlo y el más propio del operario (PyE, 95). Siente vivamente celo por reparar y aumentar la gloria de Dios, sentimientos de delicadísima conmiseración y expiación por el desdoro de esta gloria (IdH, 423). La eucaristía le alienta en esta empresa: "Tenemos una Víctima de propiciación por nuestros pecados, y los de todo el

33 El beato Mosén Sol, como hijo de su tiempo, emplea las expresiones y el estilo propios de la espiritualidad de la época. Pueden parecernos demasiado cargados de sentimientos, con abundancia de suspiros, adjetivos y exclamaciones. Debemos fijarnos en el amor que encierran y en su profundo sentido teológico (RBMDS, 25). 34 Cf. sacrificio de expiación y propiciación: Lev 16, 2-28, que es visto en el Nuevo Testamento referido a Cristo (Cf. Orígenes, Sobre el Levítico. Homilía, 9, 10; 10). 
mundo: Jesús sacramentado y sacrificado todos los días por nosotros sobre el altar" (PyE, 96)

- Ser víctimas para aplacar la ira de Dios35. Ése es el deseo íntimo del Beato Manuel Domingo y Sol: Poder ofrecer a Jesús la alegría de mi sacrificio. Yo me ofrezco a Jesús por víctima (PyE, 299). Y así lo desea para los operarios como el mejor modo de agradar a Dios: Si nos encontráramos con fuerzas para ser víctimas ante Dios por nuestros semejantes, tendríamos un medio eficaz para aplacar su ira... En nada podemos agradarle tanto como en ofrecernos víctimas por su amor (PyE, 96). La reparación es precisamente el medio eficaz de aplacar la ira de Dios (IdH, 270).

- Dar consuelo a quien sufre por nosotros, compadecer con Cristo paciente. En carta a una de sus dirigidas le dice que sufra por amor a Jesús que tanto ha sufrido por ti, pues si la Cabeza sufrió por los miembros, justo es que los miembros sufran por la Cabeza (PyE, 217). Una y otra vez vuelve sobre la idea de dar consuelo al desgarrado Corazón de Jesús, y para ello, escribe a los operarios que trabajan en seminarios que deben impedir que entren lobos en el santuario (Cf. PyE, 207), pues este fin y celo y esta compasión a Jesús ha de ser el móvil principal de nuestra consagración a la Hermandad, y más que ningún otro motivo (IdH, 91; cf. 92).

Con estos presupuestos e ideas firmemente arraigadas, Mosén Sol emprende la tarea de la reparación como desagravio y satisfacción al Corazón de Jesús. La reparación es el deber de tributar al Sacratísimo Corazón la satisfacción que se merece.

Hemos podido ver hasta aquí la vivencia íntima y personal de la reparación en don Manuel. Pero hay más. Esta experiencia existencial la proyectará sobre la Hermandad fundada por él hasta el punto de quedar marcada con este sello. Mosén Sol expone los medios internos (reglamento) y externos (corrección fraterna) de la Hermandad, pero además habla de lo que él llama el quid, el nervio y principio vivificador de su obra. Nos dice que toda la Hermandad está vivificada con el espíritu de reparación a Jesús Sacramentado (IdH, 244), éste será el distintivo interior de nuestra Obra

35 Víctimas: veta cristiana esencial, a la que es muy sensible la patrística. Un testimonio: Inmolémonos nosotros más y más a Dios, ofrezcámosle todos los días nuestro ser con todas sus acciones. Estemos dispuestos a todo por causa del Verbo; imitemos su pasión con nuestros padecimientos, honremos su sangre con nuestra sangre, subamos decididamente a su cruz... Si estás crucificado por tu culpa, saca provecho de tu mismo pecado y compra con tu muerte tu salvación. San Gregorio Nacianceno, Sermón 43, 25. 
(IdH, 268), y se debe proyectar en el apostolado de la Hermandad (Cf. IdH, 255). En una palabra, la reparación debe ser el sentimiento peculiar, constante, tierno, interior de nuestros corazones ( $\mathrm{IdH}, 246)$.

Otras facetas aparecen en la idea de reparación de Mosén Sol, entre ellas ver ahí el medio de perfección: Este sentimiento continuo de amor y compasión hacia Jesús Sacramentado constituye, o produce al menos, la perfección (IdH, 247); es el medio indefectible de perfección (IdH, 255). Ve, además, en la reparación, el alivio de nuestras penas, el consuelo en todas las tribulaciones (IdH, 265) en el difícil ministerio pastoral, lo que devolverá la paz y la alegría (Cf. IdH, 266-268).

\subsection{En sintonía con la Iglesia y teología de su tiempo}

Los documentos del magisterio sobre la reparación hasta mediados del siglo XX se mueven en las mismas coordenadas de la época de Mosén Sol. Ésta es la tónica de los antes citados de León XIII, Pío XI y Pío XII.

Veinte años después de la muerte del Beato Manuel Domingo y Sol, Pío XI publica la encíclica Miserentissimus Redemptor, documento emblemático sobre la reparación, en el que destaca tres aspectos: penitencia, compasión y ofrenda victimal. Este esquema responde a la génesis histórica de la reparación. Recordemos algunas ideas.

El Papa habla de compensar las injurias de algún modo inferidas al Amor increado, si fue desdeñado con el olvido o ultrajado con la ofensa. A este deber llamamos vulgarmente reparación (n. 6). Esta reparación de desagravio produce grandes frutos (Cf. n. 22), y Pío XI la encarece y ordena a toda la Iglesia ${ }^{36}$. E incluso el Papa extiende el deber de reparación a todo el género humano ${ }^{37}$. Pío XI esgrime para justificar esta

36 Deseamos con ardor que la costumbre de esta expiación o piadosa reparación, introducida desde un principio santamente y santamente propugnada, sea asimismo aprobada con más fuerza por Nuestra Apostólica autoridad y con más solemnidad practicada por todos los católicos. A este fin disponemos y mandamos que cada año en la fiesta el Sacratísimo Corazón de Jesús en todos los templos del mundo se rece solemnemente el acto de reparación al Sacratísimo Corazón de Jesús para que se reparen nuestras culpas y se resarzan los derechos violados de Cristo, Sumo Rey y amantísimo Señor (MR, 22).

37 Este deber de expiación a todo el género humano incumbe..., que había merecido ser arrojado a la ruina sempiterna..., ya que desde el principio los hombres en cierto modo reconocieron el deber de aquella común expiación y comenzaron a practicarlo..., ofreciendo a Dios sacrificios, aun públicos, para aplacar su justicia (MR, 8; cf. 10). 
reparación los motivos de justicia y amor38. El Papa habla de consolar a Cristo (n. 14), pues podemos y debemos consolar a aquel Corazón Sacratísimo, incesantemente ofendido por los pecados y la ingratitud de los hombres (n. 15).

Al final de la encíclica MR, Pío XI incluye la Oración expiatoria al Sagrado Corazón de Jesús para ser rezada en toda la Iglesia. En ella comprobamos que tanto el enfoque de la reparación, las ideas vertebrantes e incluso el vocabulario empleado es sensiblemente igual a lo visto en Mosén Sol39.

El sentido de reparación de Mosén Sol recibe el reconocimiento de la Iglesia en el Decretum laudis de la Secretaría de la Sagrada Congregación de obispos y regulares (1 de agosto de 1898)40.

\subsection{Proyección de la idea de reparación de Mosén Sol}

Don Manuel se propone extender la reparación a todos los ámbitos de la Iglesia. Se convierte en formador de reparadores, crea, como él mismo dice, una red de reparadores. Éstas son sus palabras: Quisiéramos formar una red de reparadores que promuevan la gloria de Dios por todos los ámbitos de España, y no solo de España, sino hasta de la India y de China (PyE, 88; cf. 175).

38 Con apremiante título de justicia y amor, estamos obligados al deber de reparar y expiar: de justicia, en cuanto a la expiación de la ofensa hecha a Dios por nuestras culpas y en cuanto a la reintegración del orden violado; de amor, en cuanto a padecer con Cristo paciente y saturado de oprobio y, según nuestra pobreza, ofrecerle algún consuelo". No basta el culto de adoración o la alabanza en acción de gracias, "sino que, además de esto, es necesario satisfacer a Dios..., ha de añadirse la expiación (MR, 7).

39 Éstos son algunos pasajes de la fórmula, en los que vemos confirmado lo dicho: Dulcísimo Jesús, cuya caridad derramada sobre los hombres se paga tan ingratamente con el olvido, el desdén y el desprecio... Queremos reparar con especiales manifestaciones de honor tan indigna frialdad y las injurias con las que en todas partes es herido por los hombres tu amoroso Corazón... Estamos dispuestos a reparar con voluntaria expiación los pecados propios y del mundo... Queremos expiar todo el cúmulo de tan deplorables crímenes, nos proponemos reparar cada uno de ellos en particular... ¡Ojalá podamos nosotros lavar con nuestra sangre estos crímenes!... Te prometemos con todo el corazón compensar en cuanto esté de nuestra parte, y con el auxilio de tu gracia, los pecados cometidos por nosotros y por los demás (Puede verse el texto completo en F. Cerro Chaves, Encíclicas y documentos de los Papas sobre el Corazón de Jesús, Monte Carmelo, Burgos 2000, 65-66).

40 ... y en todo esto, los indicados sacerdotes lo practican celosamente con el fin de reparar también de alguna forma las injurias lanzadas contra el Señor, especialmente 
Primero, los operarios. Mosén Sol hace depender de la reparación el futuro de la Hermandad fundada por él: Debemos esperar firmemente que Jesús multiplicará sus bendiciones sobre nosotros y la Hermandad en proporción de nuestros actos de reparación, celo y sacrificio por su amor sacramentado ( $\mathrm{IdH}, 483)$.

Cuando somete a revisión los Estatutos a su amigo D. Benito Sanz y Forés, éste le sugirió que suprimiera la palabra reparadores del nombre de la Hermandad. Mosén Sol se resiste, y escribe: Reparadores expresa el espíritu interior y deseo que no solo vivifique, sino que sea un carácter permanente, visible, y que se incruste en los operarios, que han de hacerlo todo por espíritu de reparación a Jesús Sacramentado (Escritos, II, 13², 142).

El término reparadores lo incluye en la primera fórmula de consagración de los operarios de 1885. El anhelo de don Manuel es bien claro: Deseo no morir sin dejar iniciado el movimiento de nuestros operarios hacia la reparación de Jesús Sacramentado (Escritos, II, 9, 173; cf. 2).

La conciencia de ser reparadores la inculca constantemente cuando habla a los operarios. La vida del operario debe ser el amor y la reparación al Corazón de Cristo Jesús (PyE, 93; cf. 100), Jesucristo nos llama para que seamos reparadores de su Corazón (PyE, 97) y las prácticas de reparación han de ser objeto de nuestra inclinación especial (PyE, 100; cf. 101), o sea, por una especie de connaturalidad con la vocación del operario, que es una vocación victimal: Ofrecimiento de víctimas. Y que Jesús sea glorificado en nuestra Obra y salvadas las diócesis de España por medio de nuestros futuros reparadores (PyE, 140).

Los sacerdotes ${ }^{41}$. El objeto principal de la Hermandad (fomento, sostenimiento y cuidado de las vocaciones, sobre todo de la vocación sacerdotal) lo ve Mosén Sol impregnado de espíritu reparador. Desde el fondo de su corazón exclama: ¡Que podamos llenar el mundo de almas sacerdotales reparadoras! (PyE, 90). Llegó a elaborar un proyecto de sacerdotes reparadores bajo la tutela de la misma Hermandad, y que de alguna forma fueran auxiliares de la misma (Cf. Escritos, II, 9 179 ; III, $1^{\circ}$,

en el sacramento de su amor (Texto en SOD, 562), reconocimiento que se repite, como expusimos antes, en el Decreto por el que se confiere a la Hermandad la naturaleza de instituto secular (19 de marzo de 1952) (Texto en SOD, 566).

41 Sobre sacerdocio y reparación, cf. en la revista TN: O. Santagada, El misterio del Corazón de Jesús y el sacerdocio ministerial: 48 (1984) 62-69 y 49 (1984) 46-54. Cf. G. Manzoni, La spiritualità riparatrice..., 173-175. En el Decreto por el que se declara el martirio de Pedro Ruíz de los Paños y ocho compañeros de la Hermandad de Operarios Diocesanos (6 de julio de 1993), la Congregación de las causas de los 
$\left.8 ; 7^{\circ}, 101\right)$ Denomina el proyecto Pía Unión de Sacerdotes Reparadores, a cuyo proyecto ligaba los sacerdotes agregados 42 . La ambiciosa idea de Mosén Sol era establecer en cada pueblo y parroquia la reparación por medio de dicha Pía Unión. En 1890 redacta un breve texto para dar a conocer su proyecto43. La idea la inculcaba ya en los seminaristas a los que dice que serán los ángeles que velarán el tabernáculo día y noche en las parroquias y serán reparadores verdaderos (PyE, 208). El sacerdote, configurado con Cristo Buen Pastor, actuará ministerialmente con el Corazón del Buen Pastor, dócil a las mociones del Espíritu.

Las religiosas. El ministerio pastoral de Mosén Sol con las religiosas fue muy intenso y perduró toda su vida, como lo muestra el amplísimo epistolario que se conserva en el Archivo de la Hermandad. En las religiosas sembró también la idea de reparación, como él mismo nos confiesa: Yo deseaba que todas las religiosas fueran reparadoras del amor ultrajado del Corazón de Jesús (PyE, 266).

En 1886 pensó establecer en Roquetas (Tortosa) un convento de religiosas eminentemente reparadoras; el obispo le hizo desistir del proyecto, pero no de la idea (Cf. Escritos, III, $\left.1^{\circ}, 24\right){ }^{44}$. En su abundante relación epistolar con religiosas les alienta con frecuencia en su tarea reparadora.

Laicos. También el laicado es incorporado por Mosén Sol a la reparación. Lo intenta, sobre todo, con la institución de los Maestros católicos ${ }^{45}$. Uno de los nombres que da a dicha institución es la de Hermandad de Maestros católicos, reparadores del Corazón del Jesús.

Otros proyectos. La idea de la reparación bulle constantemente en la cabeza de don Manuel y busca diversos canales para concretarla. Proyecta lo que denomina Obra española de reparación y la Corte de amor y reparación al Corazón de Jesús Sacramentado (Cf. Escritos, III, 1, 60, 61, 62 ), aunque no todos los operarios veían claro estos proyectos sobre los

santos vincula las palabras sacerdote y hostia, de acuerdo con la teología del sacerdocio ministerial cristiano. Hay una relación peculiar entre sacerdocio ministerial y sacrificio personal, que se exigen mutuamente: el sacerdote es a la vez víctima. (Cf. Juan Pablo II, Exh. apost. Pastores dabo vobis, n. 23; la expresión suprema de ello es el martirio: cf. SOD, 574-575)

42 Cf. SOD, 88.206

43 Lo titula Breve idea de la Hermandad o Pía Unión de sacerdotes operarios diocesanos reparadores del Corazón de Jesús. Puede encontrarse el texto en SOD, 561.

44 El mismo Mosén Sol confiesa: Se me ocurrió que mejor que comunidad de religiosas, podría ser de más resultado que fuesen hombres (Escritos, III, $7^{\circ}, 101$ ).

45 Cf. SOD, 225-2237. 
que Mosén Sol trata de convencerlos (Cf. Escritos, II, 9², 207, 214). En 1892 trabaja por establecer en Madrid un centro especial de reparación eucarística, proyecto que no pudo llevar a cabo (Cf. Escritos, III, 1º, 63, 64, $65,66)$. Proyectó también un Boletín de Reparación a Jesús Sacramentado, que no cuajó.

\subsection{Espiritualidad eucarístico-reparadora}

El tema ocupa lugar primordial en la vida y ministerio del Beato Manuel Domingo y Sol, y tiene una sólida cobertura teológica. En efecto, la espiritualidad reparadora tiene su fundamento en el carácter sacerdotal y profético del bautismo, y se alimenta y desarrolla mediante una participación asidua en la vida litúrgica de la Iglesia46.

Esta espiritualidad es central en Mosén Sol, como resaltan sus biógrafos 47 . Es más que una laudable devoción privada, es una constante en la Iglesia por su estrecha relación con el Corazón de Jesús y la eucaristía. Los elementos esenciales de esta devoción al Corazón de Jesús pertenecen de manera permanente a la espiritualidad propia de la Iglesia a lo largo de toda su historia48.

El tinte eucarístico de esta espiritualidad arranca en Mosén Sol de su propia experiencia: 'Mihi vivere Christus est in sacramento': nuestra vida interior sea Jesús Sacramentado y olvidado. Con esto seremos perfectos (Escritos, I, 5, 31), y deseaba que esta espiritualidad se extendiera no solo a los operarios, sino también al pueblo de Dios, convirtiéndose así en arma del apostolado49. Ante los duros trabajos del Evangelio, ante la fuerte

46 A. Tessarolo, Reparación en A. Ancilli (dir), Diccionario de Espiritualidad, III, Herder, Barcelona 1987, 281.

47 La nota más característica de la espiritualidad del beato Manuel Domingo y Sol es, sin duda, el espíritu de reparación a Jesús en la eucaristía. Lo quiso poner como nota significativa de la Hermandad (SOD, 75). La espiritualidad eucarístico-reparadora, en la intuición y la vivencia de Mosén Sol, nos invita a apropiarnos los sentimientos de Cristo siervo, profeta y pastor en la oración de cada día y a comprometernos a hacer todo lo posible para que los demás también puedan compartirlo. Éste era su espíritu eucarístico-reparador (J. García Velasco, Manuel Domingo y Sol, un hombre de corazón, Sígueme, Salamanca 2007, 32).

48 Juan Pablo II, Carta al Prepósito general de la Compañía de Jesús. Paray-leMonial , n. 3 (4 de junio de 1999).

49 Con el propósito de hacer frente a las campañas contra la fe y la religión, Mosén Sol quería que en todas las parroquias se crearan cenáculos encendidos de amor ardiente y reparador, y que del encuentro frecuente con Cristo sacramentado salieran apóstoles seglares decididos a luchar sin descanso por el reino de Dios (J. García Velasco, O.c., 48). 
exigencia que conlleva la acción pastoral, Mosén Sol encuentra una clave que describe en estos términos: ¿Cómo se concibe tanto sacrificio? ¿Cómo se explica tanto heroísmo? Mirad a ese sagrario. Ése es el que sostiene, y sin su ayuda no podrían sostenerse en esa actividad emprendida. Ésta es la fragua donde se calienta el corazón y se enardece para sacrificarse por sus hermanos (Escritos, I, 2, n23).

El Beato Manuel Domingo y Sol deja la espiritualidad eucarísticoreparadora como herencia a la Hermandad, y la presenta a los operarios como un sentimiento peculiar, constante, tierno, interior de nuestras almas, el móvil de todas nuestras operaciones (PyE, 94). La espiritualidad es un estilo o forma de vivir la vida cristiana bajo la guía del Espíritu, identifica a la persona, es el medio por el que cada uno manifiesta su ser cristiano. Pues bien, la espiritualidad eucarístico-reparadora es la característica con la que don Manuel y los operarios deben vivir su vida sacerdotal.

Esta espiritualidad debe realizarse a dos niveles: el personal y el institucional. Por tanto, se trata también de un estilo comunitario, que configura a cada uno y configura al grupo total. Es una espiritualidad que se hereda y se transmite; arraigada en el fundador de la Hermandad, es asumida por la institución y hecha vida por todos sus miembros. Es lo que desea Mosén Sol: Lo que más ha de sostener la Obra y obtener gracias es el mantenimiento del espíritu que ha de vivificar a sus individuos, o sea, el ser reparadores de Jesús Sacramentado, de su amor (IdH, 246; cf. 265268; PyE, 93). Por eso encarece a los operarios que las prácticas de reparación han de ser objeto de nuestra inclinación especial. A continuación nos ocupamos de estas prácticas, expresión de una espiritualidad bien definida.

\subsection{Prácticas eucarístico-reparadoras 50}

La riqueza de las devociones es innegable. Las devociones permiten al

50 Abunda la bibliografía sobre la dimensión devocional de las prácticas eucarísticoreparadoras, generalmente tratadas más en el ámbito de la teología espiritual que en el de la teología dogmática. Reseñamos algunos trabajos de TN: A. Edwards, La devoción al Corazón de Jesús y la cultura del siglo XIX: 456 (1983) 62-77; E. Glotin, Juan Pablo Il en Paray-le-Monial, o ¿por qué el 'corazón'?: 62 (1987) 79-93; J. Delicado Baeza, El Corazón de Jesús, fuente de la nueva evangelización. Creación del Centro de Espiritualidad del Corazón de Jesús en Valladolid: 75 (1990) 75-96; G. Angeline, La devoción al Corazón de Jesús. Ensayo de reflexión teológico-práctica: 78 (1991) 63-80; La Civiltà Cattolica (editorial), El Sagrado Corazón de Jesús en el umbral del tercer milenio: 77 (1991) 69-79; B. de Margerie, Devoción al Sagrado Corazón de Jesús: 82 (1992) 56-66; J. M. Igartua, El encargo suavísimo del Sagrado Corazón a la Compañía de Jesús: 88 (1994) 56-68. 
cristiano más sencillo aprender con la oración las verdades más profundas de la fe ${ }^{51}$. Mosén Sol vivió inmerso en el mundo devocional de la época, y en ese ámbito del catolicismo popular se cultivaban intensamente las devociones a la eucaristía y al Corazón de Jesús.

A los 17 años se pregunta el seminarista Manuel Domingo y Sol: ¿Por qué Nuestro Señor Sacramentado no ha de tener este culto y estos adoradores todos los días? (PyE, 278). Se entrevé ya desde el principio lo que pondrá en práctica en su vida. Tomamos nota de las prácticas eucarísticoreparadoras vividas y divulgadas por Mosén Sol: vela los jueves por la noche, exposición diaria del Santísimo, adoración nocturna, visita diaria al Santísimo (Cf. PyE, 100, 278); coronilla de desagravios, media hora de visita de reparación a Jesús Sacramentado (Cf. PyE, 100, 103); fiesta del reservado o de la institución del Santísimo en las casas de la Hermandad (Cf. PyE, 176, 192).

A estas prácticas devocionales, añádanse las diversas iniciativas reparadoras puestas en marcha: Corte de reparación, Vela perpetua ante el Santísimo, Camareras del Santísimo, Operarios diocesanos reparadores y Pía unión de sacerdotes reparadores de que tratamos anteriormente así como grupos de Adoración Nocturna en diversos sitios, para culminar con los templos de reparación de que nos ocupamos a continuación 52 .

\subsection{Templos de reparación}

Este tema merece un título aparte. Estos templos los enclava Mosén Sol entre los medios externos de reparación, y es quizá el más significativo entre los muchos ideados por él.

Don Manuel concibe estos templos como un lugar de encuentro para los que se aman, para el trato de amistad con el que sabemos que nos ama y en correspondencia a ese amor. Así de sencillo. No tienen los servicios, obligaciones y ataduras propios de una parroquia, siendo la reparación su foco y objetivo. Dejemos la palabra a Mosén Sol para que nos cuente su origen. Las raíces nos las expone en estos términos: El instinto de la Obra es de una adoración quieta y silenciosa a Jesús sacramentado (IdH, 279). Esta actitud y sentimiento lo considera especialmente propio del operario: El ejercicio interior de expiación y sacrificio y de compasión a Jesús es el más eficaz para repararle y el más propio del operario $(\mathrm{IdH}, 281)$.

Durante la tristemente célebre revolución de 1868 -escribe don Manuel- un pensamiento cruzó por mi mente: el Corazón de Jesús, del cual era devoto, parecía me exigía un monumento, un lugar de víctimas agradables con el

51 L. Hertling, Historia de la Iglesia, Herder, Barcelona 1989, 224

52 Cf. RBMDS, 22-23 
objeto de desagraviarle de los pecados del mundo (IdH, 272). Primero, simple sentimiento, después fue idea lentamente rumiada hasta alcanzar la madurez. Ha visto claro el objetivo: Tengo resuelto el problema de la promoción de la reparación ( $\mathrm{IdH}, 273$ ), lo que hay que buscar son los medios para verlo realizado. Mosén Sol da rienda suelta a su imaginación: Mis ambiciones no están satisfechas. Pido a Jesús que, si es su voluntad, pueda ver una docena, al menos, de reparaciones y otras tantas cortes de amor y expiación diocesanas... Si tuviera más jóvenes, haríamos un templo de reparación en cada pueblo, para reparar a Jesús de las muchas ofensas que recibe $(\mathrm{IdH}, 275)$.

Reconstruyamos el itinerario seguido por Mosén Sol. A los 20 años, le vino la idea de levantar en Tortosa un templo de reparación ${ }^{53}$. En 1859, siendo diácono, idea una Capilla reparadora en la catedral de Tortosa (Cf. IdH, 271). En 1875, nos habla de levantar un monumento para honrar especialmente al Sagrado Corazón de Jesús con el objeto de desagraviarle de los pecados del mundo $(\mathrm{IdH}, 272)$ y en 1892 habla de múltiples proyectos, bosquejados y que duermen hace tiempo en un cajón (IdH, 276), mostrando su confianza de lograrlo en Tortosa, Madrid, Valencia, Sevilla, Granada, Córdoba... bajo la dirección de los operarios (Cf. IdH, 276, 278). Su ilusión no tiene límites ${ }^{54}$. En 1896 declara que ha visto con absoluta claridad el plan a seguir sobre el funcionamiento de los templos de reparación.

Sus ansias se ven colmadas sobre todo con el Templo de reparación de Tortosa, que inaugura por fin en 1903. Ha hecho gestiones con el obispo en 1900 para erigir el tempo (Cf. IdH, 274), cumpliéndose así el deseo que viene de cuando contaba 20 años. En el Tempo de Tortosa descansan hoy sus restos. En el entretiempo, se abre el Templo Nacional Expiatorio San Felipe de Jesús, México, en 1899.

La idea de reparación de Mosén Sol ha quedado fielmente plasmada en los templos de reparación. Son lugares especialmente de culto al Corazón de Jesús Sacramentado, impregnados por la idea de amistad con Jesús eucaristía, de desagravio, de expiación, de compasión por las ofensas que recibe; ahí se fraguan las víctimas, la oblación, el sacrificio y la adoración quieta y silenciosa. Por otra parte, los templos de reparación serán una palanca fundamental para fomentar el apostolado reparador.

53 Cf. SOD, 75

54 En una carta escribe: Confío tener Madrid, Valencia, Tortosa... A ver si con sus oraciones logra usted que la reparación se establezca en Sevilla, Granada, Córdoba... Me vuelvo viejo. Dime, ¿qué haríamos si fuésemos jóvenes? Haríamos un templo de reparación en cada pueblo, para reparar a Jesús las muchas ofensas que recibe (PyE, 278) Sueña, además, con una capilla reparadora en Lisboa (Cf. Escritos, II, 9², 179). 


\section{LÍMITES Y VALORES DE LA REPARACIÓN TRADICIONAL}

\subsection{Límites}

Los límites de la reparación tradicional, que es la de Mosén Sol y su tiempo, son claramente perceptibles hoy y el lector actual los percibe fácilmente en lo expuesto hasta ahora. Es una reparación que fomenta una fuga hacia el intimismo, hacia el individualismo religioso, es un refugio hacia el mundo espiritual; fomenta el sentimentalismo, se inscribe en un clima devocional-espiritual y relega el compromiso; avoca a una actitud dolorista y a una actitud pasiva, con el riesgo de abandonar la realidad urgente de los grandes problemas en los que se debate el mundo y que debe afrontar el cristianismo55.

Estos límites guardan estrecha relación con los soportes teológicos de la modalidad tradicional, entre los cuales señalamos los siguientes:

Cristológico. La cristología gravita sobre el Cristo sufriente y doloroso de la pasión, dominante en el segundo milenio y que acapara el escenario teológico a partir de la cristología-soteriología de san Anselmo. Esta cristología no tenía debidamente en cuenta la cristología del Señor glorioso, en la que tanto se insiste en la teología actual.

Antropológico. La vida cristiana estaba marcada profundamente por el pecado del hombre, lo que desembocaba en una antropología típica de la humanidad caída y pecadora, vista como la que niega a Dios el honor debido, sino que más bien le injuria y ofende. Todo ello abocaba a una determinada postura pastoral fomentada en la Iglesia, lo que se manifiesta de modo claro en la celebración de la semana santa. En este contexto, el hombre-reparador vendría a ser el contrapeso del hombre-pecador.

El pecado domina la escena teológica, pero debemos hacer la siguiente reflexión: el pecado es una posibilidad real, más aún, una posibilidad que acontece de hecho en la historia, pero no es propiamente un constitutivo de la naturaleza humana. Por otra parte, Jesús se encarna primariamente no para quitar el pecado, sino para divinizar al hombre y mostrar así la grandeza de la naturaleza humana: Yo he venido para dar vida a los hombres y para que la tengan en plenitud (Jn 10, 10), y el Vaticano II enseña que vino para descubrir al hombre su ser más íntimo, su misterio (Cf. GS 22b).

55 Una buena presentación de estos límites en A. Tessarolo, a.c., 279-281. Obras representativas de esta tendencia pueden ser J. Hartmann, Le sens plènier de la réparation, Lovaine 1955; A. Pellin, Vida de reparación, Madrid 1966; G. Denis, Spiritualità riparatrice, Pescara 1955. 
Espiritual. La espiritualidad enfatiza la relación íntima y directa con la persona del Señor, lo que traduce y expresa en múltiples devociones y prácticas religiosas características de la reparación tradicional. Tal orientación conduce al intimismo, al subjetivismo religioso, a la compasión con la persona sufriente y ofendida de Cristo, quedando marginado el compromiso con el proyecto del Señor.

La consideración de estos límites a partir de la teología del Vaticano II llevará a un giro en la concepción de la reparación. Estos límites de la reparación tradicional no están tanto en lo que dice (como veremos en los valores que expondremos a continuación) como en lo que no dice o no acierta a decir debido a la teología de la época.

\subsection{Valores}

La comprobación hecha de los límites no puede ocultar los auténticos valores de la modalidad tradicional de reparación. Es lo que expondremos a continuación.

- La intimidad con Cristo, valor permanente

Jesús eligió a los Doce en primer lugar para estar con él (Mc 3, 13), enraizándolos profundamente en la escuela de Jesús, salvando así la realidad fundante y decisiva que es Dios; en esa escuela se aprende a denunciar el poder deletéreo del mal y del pecado.

¿Quién conoce a Dios? El que está en el seno del Padre lo ha contado (Jn 1, 18); solo el Hijo conoce al Padre y solo él lo revela al hombre (Cf. Mt 11, 27). Solo en la escuela de Jesús se aprende a conocer a Dios. No se puede ser testigo de alguien a quien no se conoce; es necesario que se experimente al Señor no como un personaje de la historia pasada, sino como el Cristo vivo y presente. Él es el Viviente (Cf. Ap 1, 18; 2, 8) que camina a nuestro lado, y lo hace con un amor hasta el extremo, simbolizado en su Corazón traspasado por nosotros, y que se nos da sin reserva en la eucaristía. Tengamos en cuenta que la reparación es a la manera de un sacramento que realiza una unión intensa del creyente con Cristo doliente (T. de Chardin).

La intimidad con Jesús se hace imprescindible y nos lleva a la escucha y al silencio contemplativo que proporciona paz: Vengan ustedes solos un lugar deshabitado, para descansar un poco (Mc 6, 31-32). Con Juan Pablo II nos preguntamos: ¿Dónde te encuentras para abrir un auténtico proceso de conversión, comunión y solidaridad?56.

56 Exhort. apost. "Ecclesia in America”, n. 8 
Más aún, no es que nosotros busquemos la intimidad del Señor, es él quien toma la iniciativa y nos llama por el propio nombre (Cf. Jn 10, 3): Mira que estoy de pié junto a la puerta y llamo. Si alguno oye mi voz y abre la puerta, entraré en su casa y cenaré con él y él conmigo (Ap 3, 20). El Señor nos habla hoy a nosotros, hambrientos de oír la Palabra del Señor (Am 4, 8). Por eso, es necesario acudir a él, obedientes a su invitación: Si alguien tiene sed, que venga a mi y beba. Como dice la Escritura, de lo más profundo de todo aquél que crea en mi brotarán ríos de agua viva (Jn 7, 37-38; cf. 4, 13-14).

En el Corazón de Jesús Sacramentado encontró Mosén Sol esa fuente de agua viva, la "fonte que mana e corre, aunque es de noche" (San Juan de la Cruz) La gran tradición cristiana y teológica ha recogido esta idea57.

- El Amor debe ser correspondido: 're-damatio'

El marco es la pasión del dolor y la pasión del amor. El Corazón de Jesús herido no significa la sacralización el dolor, sino la santificación el sufrimiento por el amor. La cruz es ante todo símbolo de un amor extremo.

La palabra reparación, que no goza hoy del favor popular, está unida históricamente al concepto paleocristiano de redamatio, o sea, devolver amor por amor58. Redamatio evoca respuesta esponsal; es el retour d'amour o recambio de amor (P. Dehon). El refranero popular dice que amor con amor se paga, y el canto litúrgico navideño: Sic nos amantem, quis non redamaret?.

Dios nos precede en el amor (Cf. Rom 5, 8.10), y Él nos amó a nosotros, y envió a su Hijo como víctima por nuestros pecados (1Jn 3, 10)59. La reparación como redamatio adquiere así un valor constante. Es un acto de amor nuestro, que integra todos los actos de la vida humana. Es además un apostolado en sentido pleno, no una mera devoción, que afecta a la raíz de la vida cristiana. Cuando Jesús contempla al Padre ofendido, esa ofensa le Ilega al alma. ¿No debemos sentir como Cristo esas ofensas al Amor que no es amado?.

57 La saciedad, el placer, el sosiego están en descansar en Dios y contemplar su fidelidad. En él está la fuente viva. Acudamos a esa fuente (San Ambrosio, Sobre la huída del mundo, cap. 9, 52).

58 Cf. P. Kolvenbach, citado por F. López-C. Soltero-Mª Celayeta, CSCJ, 93-94.

59 Comentando este pasaje, san Agustín expone el motivo para amar a Dios: Trata de averiguar de dónde viene al hombre poder amar a Dios, y no encontrarás otra razón, sino porque Dios mismo lo amó primero. Se entregó a sí mismo para que lo amáramos y con ello nos dio la posibilidad y el motivo de amarle... Por tanto, teniendo una gran confianza, amemos a Dios en virtud del mismo don que Dios nos ha dado" (Sermón 34, 2-3). 
La reparación será una consecuencia lógica entre dos personas que se aman. El amor de Mosén Sol a la eucaristía es el resultado de la intimidad de dos corazones que amando se han identificado en los mismos sentimientos de gozo y de dolor. El Señor, deseando ser amado en su Corazón, hace un nuevo llamamiento a las almas para que acudan a este convite suave de su amor, para que reparen el desvío de tantos que no escuchan su invitación. Tal es el grito de reparación que dirige con voz sentida a todos los corazones, y tal es el llamamiento al cual debemos responder (Escritos, I, 1, n128).

El amor es la base. En la devoción al Corazón de Jesús ve don Manuel el amor infinito en que se ha abrasado por nosotros. En ella nos proponemos pagarle amor por amor..., y reparar los ultrajes que recibe, sobre todo, en el sacramento de nuestros altares. Y este amor y esta devoción la exige a todos (Escritos, I, 1, 125) Mosén Sol piensa en primer lugar en todos los cristianos, en segundo lugar en los sacerdotes y, de forma más directa e insistente, en los operarios fundados por él con el distintivo reparador.

La reparación es para Mosén Sol y quiere que sea para los demás una forma de vivir y expresar el amor. Amar a Jesús equivale a poner toda la vida en sintonía con la suya, de forma que esto se traduzca en palabras y acciones, en compromiso cristiano.

- Ante la soledad y abandono de Jesús

Jesús experimentó en su vida mortal la soledad y el abandono más profundos. No podemos pasar como de puntillas sobre los datos nos proporcionan los evangelios.

La liturgia del Viernes santo nos pone ante un espectáculo estremecedor, al aplicar a Jesús la situación de soledad y de abandono extremos en que se veía la ciudad santa, tal como nos lo narra el libro de las Lamentaciones: Ustedes, los que pasan por el camino, miren y vean si hay dolor semejante al dolor que me atormenta $(1,12)$. La soledad es vivida en su máxima intensidad: No tengo quien me consuele, nadie que me reanime $(1,16)$. acudo a mis amantes, pero ellos me abandonaron" $(1,1)$ La gente oye mis gritos, pero nadie me consuela $(1,21)$ Estoy saciado de amargura $(3$, 15.19). El dolor del oprimido se expresa en lágrimas y gritos de auxilio (cf. $2,11 ; 3,48.49 .51)$ y con la bebida de ajenjo y de veneno $(3,15.19)$.

¿Hacia donde dirigir la mirada? Todos nuestros enemigos comentan nuestro fracaso. Miedo y muerte nos han tocado en suerte, exterminio y ruina (3, 46-47), de forma que ha cesado la alegría de nuestro corazón (5, 15) Un hilo de esperanza queda y es la mirada hacia Dios: Conviértenos a ti, Señor $(5,21)$, esperanza que recorre como contrapunto todo el libro de las Lamentaciones. 
Ha sido recurrente en la patrística aplicar a Jesús los salmos de dolor del salterio.

Jesús experimentó el abandono de los suyos en su vida pública. Nos lo narra Juan: Muchos de sus discípulos se retiraron y ya no andaban con él. Entonces Jesús preguntó a los Doce: ¿Acaso también ustedes quieren irse? (Jn 6, 66-67). En ese momento, el grupo de los íntimos le permaneció fiel, pero al final, en la hora de la prueba suprema, todos sus discípulos lo abandonaron y huyeron (Mc 14, 50).

Pero la soledad y el abandono hacen presa en la carne de Jesús de forma especial en la hora trágica de la Oración del Huerto: Comenzó a sentir tristeza y angustia (Mt 26, 37), y se lo comunicó a sus discípulos que le acompañaban: Me muero de tristeza (Mt 26, 38; Mc 14, 34), saliendo de sus labios un sentido reproche: ¿De modo que no han podido velar conmigo ni siquiera una hora? (Mt 26, 40 par) Y el cenit de la soledad la experimenta dirigiéndose al Padre: Dios mío, Dios mío, ¿Por qué me has abandonado? (Mt 27, 46; Mc 15, 34).

La experiencia de Jesús en el Huerto de los Olivos ha sido la principal referencia de los reparadores de todos los tiempos; ahí se enraíza la devoción popular de la Hora santa. La súplica de Jesús pidiendo compañía no podrá dejar indiferente al pueblo cristiano.

- Frente al peligro del activismo y la exterioridad con olvido de la profundidad

El corazón y las manos. Escribe Mosén Sol: Hoy como siempre, como en los días de Moisés, no basta pelear varonilmente en el llano, sino que es preciso que allá en la montaña de la oración y del sacrificio haya manos levantadas (IdH, 269: Discurso en la Asamblea general de Asociaciones Católicas reunidas en Tortosa los días 7 al 11 de diciembre de 1887). La Iglesia ha tenido siempre en suma estima la vocación contemplativa, la oración de esos siervos inútiles para el mundo. La oración es el alma de todo apostolado como nos recuerda el Papa actual: La experiencia del amor vivida mediante el culto al costado traspasado del Redentor nos protege del peligro de encerrarnos en nosotros mismos y nos hace más disponibles a una vida para los demás60.

- También los sentimientos

La racionalidad del hombre no se agota en lo cerebral, sino que abarca también los sentimientos, los afectos y el corazón, como nos enseña la

60 Carta de Benedicto XVI al P. Kolvenbach, Prepósito general de la Compañía de Jesús, con motivo del quincuagésimo aniversario de la encíclica de Pío XII Haurietis aguas. 
sana antropología y, por otra parte, la concepción bíblica del hombre como imagen de Dios. Consiguientemente, la espiritualidad cristiana incluye también sentimientos, y refiriéndose a la imagen misma de Dios, lo revela como un Dios que tiene corazón. En un ambiente de racionalidad pura y de pragmatismo técnico, la devoción al Corazón de Jesús no puede dejar de sufrir la degradación de lo emocional, que, sin embargo, forma parte integrante de la riqueza de la existencia humana... Despreciando el sentimiento, los cristianos están haciendo del cristianismo una abstracción, es decir, una gnosis, y las abstracciones no tienen necesidad de corazón61.

Es necesario que vibre la cuerda de la adoración, la alabanza y la contemplación, con frecuencia atrofiada por el racionalismo y por una espiritualidad demasiado desnuda, para dar paso a una relación gratuita, cálida y dialogal con Dios.

\section{- La reparación ante el nuevo milenio}

Se ha generalizado la opinión de que nos hallamos ante un nuevo cambio epocal, reconocido por el Vaticano II en GS, debido a las profundas transformaciones socio-políticas, culturales, económicas e incluso religiosoeclesiales. ¿Dónde queda en este contexto la reparación y el culto al Corazón de Jesús? ¿Tienen algo que decir al mundo? El reconocimiento agradecido del amor de Jesús a la humanidad sigue teniendo sentido desde la perspectiva de la fe, y ello no por buscar irenísticamente una concordancia de tendencias, sino porque responde a la entraña del cristianismo y a las situaciones humanas por las que pasa el hombre.

La reparación y el culto al Sagrado Corazón de Jesús es un impulso a seguir a Jesús y a proseguir su misión, y ello porque la relación personal e íntima con el Señor está en el centro de la vida cristiana. Ésta será siempre una fuente y una referencia esencial, como nos lo muestra la historia. Ésta es la apreciación que hacen de Mosén Sol sus biógrafos. En su tiempo, como muchos otros apóstoles, Mosén Sol aludía frecuentemente a la reparación. Él la entendía y la vivía como un estudiar los sentimientos de Cristo redentor del hombre, con el fin de convertirlos en motor de toda su acción"62. Para don Manuel, la fuente de toda su vida y acción hay que situarla en el Corazón de Jesús Sacramentado. La Iglesia hoy lo ha reconocido a su modo, dirigiéndose a la Hermandad fundada por Mosén Sol: A la luz de esta frecuencia de trato y de experiencia cotidiana con el Corazón del Redentor, sigue conservando aún hoy en día originalidad e

61 P. Kolvenbach, Alocución a los jesuitas en Paray-le-Monial, cita en L. López-C. Soltero-Ma Celayeta, CSCJ, 90.

62 J. García Velasco, Manuel Domingo y Sol, un hombre de corazón, Sígueme, Salamanca 2007, 32. 
identidad propia la iniciativa de dar vida a una Hermandad cuyos compromisos apostólicos...63.

\section{EL NÚCLEO DE LA REPARACIÓN DE MOSÉN SOL ABIERTO A LA MODALIDAD ACTUAL DE REPARACIÓN}

\section{1. El núcleo de la reparación en el Beato Manuel Domingo y Sol}

Amor y reparación (Escritos, I, 1, 106). Con estas dos palabras nos ofrece Mosén Sol la mejor y más exacta síntesis de su idea de reparación. Ésta arranca y se explica desde el amor al Corazón de Jesús Sacramentado.

Solo a través de la reparación podemos adentrarnos en su intimidad, descubrir uno de los nervios más ricos de su espiritualidad, auscultar los latidos de su corazón apostólico, apreciar las distintas facetas de sus ministerios y captar mejor la originalidad de la Hermandad por él fundada... La reparación no es una idea circunstancial que en un momento determinado le pasa por la mente y vuelve a quedar en el olvido hasta que alguien la descubre y la vuelve a dar actualidad. Para D. Manuel, la reparación es un estilo de vida que mueve todos sus pasos ${ }^{64}$.

Mosén Sol no elabora una Teología de la reparación, sino que la encarna en la vivencia personal de intimidad con Cristo. Esta reparación contiene el sentido más evangélico y teológico de comunión y de misión del cristianismo, aunque él no tratara el tema sistemáticamente. La reparación rebasa teológicamente por todas partes los límites de una simple devoción.

Formamos un cuerpo cuya Cabeza es Cristo y nosotros su cuerpo; todo lo que sucede a la Cabeza hace referencia al cuerpo total. La reparación en don Manuel hay que entenderla en la dimensión teológica de la fe y de la comunión, aunque a veces el lenguaje y el estilo de expresarse, propio de una época determinada, pueda parecer demasiado sensible y menos teológico. Parte del hecho fundamental del misterio de un Dios encarnado que nos ama, sufre y se entrega, y con él se siente profundamente solidario. La reparación en el Beato Manuel Domingo y Sol debe ser leída en clave de amistad, intimidad, comunión y solidaridad con la persona de Jesús.

La intimidad con Jesús la expresa Mosén Sol en términos especialmente cálidos y familiares: ¡Pobre Jesús! ¡Pobre Jesús! Haced que sepa

63 Carta de su santidad Juan Pablo II a los Sacerdotes Operarios Diocesanos al cumplirse el I Centenario de la fundación de la Hermandad (25 de enero de 1983), texto en SOD, 570.

64 RBMDS, 7.10 
compensar con mis afectos de compasión tantos olvidos, tanta soledad, y aumentad en mi el espíritu de amor y reparación a vuestro Corazón Sacramentado (Escritos, I, 1, 42). Aquí radica la clave de su reparación: Amor y reparación. Una sincera y tierna compasión y el deseo de reparación brotan al contemplar las ofensas que se hacen a Dios, y que don Manuel conoce y quiere compartir en comunión de sentimientos con el Corazón de Jesús (Cf. Escritos, I, 1, 113). Si la reparación consiste en acompañar a Cristo haciéndonos partícipes de sus vivencias ${ }^{65}$, Mosén Sol lo vive intensamente en el hoy del Señor sacramentado cuando escribe este texto que consideramos fundamental para interpretar su pensamiento:

Jesucristo continúa sobre la tierra sacramentado, sufriendo místicamente las mismas injurias, las mismas infidelidades que recibió en los días de su vida mortal... El mismo Jesús de entonces vive hoy real, vivo y verdadero entre nosotros, sacramentado y rodeado su Corazón de las espinas que le ponen los pecadores (Escritos, I, 1, 103), y sufre no con sufrimientos físicos como entonces, porque está impasible, pero sí con sufrimientos místicos y espirituales (Escritos, I, 1, 41).

En conclusión: reparar en Mosén Sol es una forma de amar. Amor y reparación se autoimplican en él, el suyo es un amor reparador y su itinerario vital y apostólico está guiado por el espíritu de reparación. En el fondo, sigue la pauta de san Pablo cuando dice que la fe actúa por medio del amor (Gál 5, 6), y la oración litúrgica pide al Señor que el misterio celebrado en la fe se actualice siempre en el amor.

Esta idea fundamental, la reparación presidida por el amor, pertenece a la mejor teología cristiana sobre la satisfacción, como es el caso de Santo Tomás de Aquino, aunque no me consta que Mosén Sol lo conociera directamente. Para el Aquinate, Cristo repara con su pasión en cuanto ésta es la revelación del amor de Dios, pues la simple muerte de un inocente para satisfacer es inútil, injusta y cruel. Para Santo Tomás, Jesús es el instrumento intrínseco del Amor66. La satisfacción no es jurídica, sino que se basa en el amor; pesa más en Jesús el amor que la justicia de reparar a Dios; lo que se impone es la misericordia: La liberación del hombre por la pasión de Cristo corresponde a la misericordia y justicia divinas ${ }^{67}$. La satisfacción no es un cúmulo de dolores, sino el acto de amor en el que Jesús vivió su abandono; la justicia no es aquí conmutativa, sino misericordia que se traduce en justicia.

65 Ibid., 17

66 Instrumentum coniunctum divinitatis, expresión rica y feliz: es la instrumentalidad divinizante de la humanidad de Jesús (Cf. Suma Teologica, III, q. 7, a. 1 ad 3; q. 8, a 1 ad 1 ; q. 13, a. 2).

67 Ibid., III, q. 46, a. 1 ad 3. 
La liberación del pecado tiene que ser penitente y la satisfacción es la expresión de esa penitencia. Cristo, al asumir la condición humana, tomó la condición de penitente y así se comprometió por el camino de la satisfacción.

El pecado es ante todo un acto contrario a la caridad68, y solo la caridad lo vence. Así lo venció Cristo en él y en nosotros. Él hace nuestra su gracia, gratia Capitis, o sea, la gracia de la Cabeza del cuerpo que somos nosotros. El mérito de su acción graciosa no depende del sufrimiento, sino del amor de caridad y de la obediencia libre con que Jesús se ofreció al Padre a favor de los hombres. El mérito de Jesucristo es proporcional a su infinito amor; su cruz, más que causa de nuestra salvación, es signo del amor salvífico de Dios; la cruz de Jesús es consecuencia de su amor, no un castigo.

En la satisfacción no se busca solamente la restauración de la equidad por la justicia (enfoque jurídico), sino más bien la reconciliación en la amistad entre el ofensor y el ofendido.

\section{2. Relectura de Mosén Sol desde la perspectiva de la reparación actual}

Debemos precavernos del anacronismo de atribuir a Mosén Sol lo que ni pensó ni escribió (como por otra parte, puede decirse de los hombres de su época), reafirmándonos en la idea de reparación que hemos expuesto en este trabajo. Pero, hecha esta aclaración, podemos afirmar que su idea de reparación no es incompatible con lo que hoy se piensa sobre el tema, más aún, que su concepción de la reparación está abierta a la modalidad actual, o sea, a una reparación social y comprometida. Insistimos en la denominación de abierta, porque el camino para mostrarlo será la vía de lo implícito e indirecto, pero real, o sea, argumentaremos desde la proyección de la reparación en las obras que Mosén Sol emprende.

El amor genera necesariamente comunión con la persona amada y solidaridad con su proyecto y destino. Pues bien, las múltiples obras de apostolado que emprende Mosén Sol, a comenzar por el origen de la Hermandad, tienen una clara finalidad: agrupar a todos en una plegaria de amor y reparación ${ }^{69}$, poner en movimiento el apostolado reparador y comprometerse con el mismo. Hay una innegable proyección pastoral de la reparación de don Manuel. La configuración con Cristo no se queda en una simple contemplación de su pasión y sufrimiento, en una visión sentimental y pietista del dolor de Jesús, ni se limita a compadecerlo y sufrir con él

68 Ibid., I-II, q. 88, a. 2c; q. 59, a. 4.

69 SOD, 139 
ofreciéndose como víctima, sino que se proyecta en una actividad apostólica, lo que Mosén Sol llama celo pastoral, expresión de amor y consecuencia del envío que hace el Señor (Cf. Escritos, I, 7, 1). La sintonía y solidaridad con Jesús empuja al fundador de la Hermandad a la acción en las más variadas formas de apostolado. Suscribimos la siguiente valoración de la actividad pastoral de don Manuel leída en clave de reparación social:

Alli donde hay una necesidad eclesial -vocaciones, formación sacerdotal, misiones, juventud...-, donde hay una estructura social viciada que corrompe a las personas -juventud, mundo obrero, prensa laica beligerante contra lo cristiano...-, o una plataforma desde la que se puede comenzar una renovación -asociación de maestros, adoración nocturna, misiones populares, templos de reparación...-, allí va don Manuel con su celo reparador. Y esto mismo es lo que ofrece a los operarios... Cualquier apelativo se le podrá dar a don Manuel, cualquiera menos el de ser un hombre pasivo, intimista y no comprometido con la realidad. Desde su vida de reparador debe entenderse su concepto de reparación. No desde otros esquemas ${ }^{70}$.

El espíritu de reparación lo lleva a todas las obras que emprende, o, quizá mejor, todas las obras son fruto de su espíritu reparador, de corregir, de enderezar lo que está mal. De esta forma, la reparación desborda cualquier reduccionismo de una piedad personal, en que se puede haber caído, y se abre a una participación en la acción salvadora de Cristo, mediante el hecho conjunto del cambio personal y de la reforma de las estructuras sociales. De hecho, Mosén Sol aplica la reparación no solo a una parcela de su apostolado, sino a todas las actividades de la Hermandad.

El punto de partida de toda reparación es el amor que nos une con Dios, con Jesús y con los hombres. La reparación en Mosén Sol no se acaba en un acto de piedad, sino que se extiende a todo su polifacético apostolado y abraza todas sus actividades, pero siempre el punto de partida hay que buscarlo en el amor. Un amor que le lleva a restaurar lo que no responde al plan de Dios y a procurar los medios adecuados para lograrlo.

Precisamente es eso lo que pretende don Manuel en su apostolado con la juventud, con la prensa, con los obreros, con la formación del clero... En síntesis, podemos afirmar que la reparación en don Manuel tiene dos dimensiones: la eucarística y la social. Ambas en él van unidas ${ }^{71}$.

Reparación social o de proyección universal. La cruz y el sagrario se actualizan en cada situación. No basta reparar los pecados personales, hay que reparar también los pecados de los grupos, los de las estructuras, los de la misma sociedad. Esta reparación social viene impulsada en el Beato

70 RBMDS, 32; cf. 40-41

71 Ibid., 22 
Manuel Domingo y Sol, como hemos repetido tantas veces, por la eucaristía y la devoción al Corazón de Jesús. La reparación social nos hace solidarios los unos de los otros: Desgraciados si nosotros, hermanos, no correspondemos a los sacrificios que el Señor nos exige a favor de nuestros hermanos (Escritos, I, 11, 16) El amor intenso a Jesús eucaristía y al Corazón de Jesús proyecta a Mosén Sol sobre la causa de Jesús y su proyecto del Reino de Dios en el mundo. Por eso, más allá del estilo y lenguaje de la época, debemos fijarnos en el amor que encierra y en su profundo sentido teológico. Su idea es clara: hay que restaurar, renovar o reformar lo que está roto: a nivel de personas y de estructuras, con la oración y con la acción ${ }^{72}$. El amor a Dios y el amor al hombre se funden en un mismo sentimiento: la reparación a Cristo en el hombre que cae y sufre se convierte en reparación social. Sí, también los males corporales del hombre (Cf. Escritos, I, 1, 113) Este tipo de reparación anuda la com-pasión con la solidaridad; nada de Cristo es ajeno a don Manuel, tampoco nada que diga referencia al hombre en sus necesidades.

Cuando la Hermandad de Sacerdotes Operarios opta por el giro de la reparación tradicional a la actual a partir del Vaticano II, encuentra en don Manuel pistas para el compromiso con el mundo y el dolor de los hombres: Su espiritualidad tiene un singular acento eucarístico-reparador que se concreta en la propia celebración como culmen de la caridad fraterna y compromiso con el mundo, en una mayor sensibilidad por el sentido del dolor de Dios y de los hombres (AG XVII, 1.1.3) Aunque de lejos, Mosén Sol intuyó la actualidad del sufrimiento de Cristo, ahora en su rostro deformado de la víctimas del pecado del mundo, como queda de manifiesto en sus propias palabras: Jesucristo, hermanos míos, continúa sobre la tierra sacramentado 'sufriendo místicamente' las mismas injurias, las mismas infidelidades que recibió en su vida mortal. El mismo Jesús de entonces vive real, vivo y verdadero entre nosotros, sacramentado (Escritos, I, 1, 103), aun cuando sabemos que el Señor resucitado está exento del sufrimiento físico (Cf. Escritos, I, 1, 41).

La reparación es una forma de vivir el amor, que nos empuja a una acción apostólica sin descanso en los más variados campos. Siempre habrá algo en la vida que se pueda conseguir, algo que se pueda evitar cuando el amor nos urge desde dentro. Refiriéndose a la eucaristía, Mosén Sol escribe: Ésta es la fragua donde se calienta el corazón y se enardece para sacrificarse por los hermanos. Más pequeño en el tabernáculo que en la cuna, más pequeño en la hostia consagrada que en el pesebre... Y aún te haces más pequeño. ¿Cómo? Entrando sacramentado en mi corazón (Escritos, I, 1, 14), y animando desde ahí todo nuestro ser y nuestro obrar.

72 Ibid., 25 